\title{
Method of the Analysis of Gender Segregation at the Regional Labour Market
}

\author{
Tatyana V. Sarycheva \\ Lyudmila P. Bakumenko \\ Mari State University, Yoshkar-Ola, Russia \\ Email: tvdolmatova@bk.ru \\ Vladimir S. Mkhitaryan \\ Tatyana A. Dubrova \\ National Research University Higher School of Economics, Moscow, Russia \\ Email:vmkhitarian@hse.ru
}

\section{Doi:10.5901/mjss.2015.v6n3s7p161}

\section{Abstract}

The labour markets of both a region and a country are characterized by a certain level of gender segregation. For the objective assessment of this phenomenon it is necessary to have a clear understanding of how this level changes over time, which processes at the labour market and in society facilitate the increase or decrease of gender asymmetry in the distribution of employees between economic activities and occupations and which economic consequences are caused by segregation. The questions raised are studied in the paper in terms of the dynamics of employed by the economic activities, which on the one hand reflects the desire of workers to be employed in certain activities and, on the other hand, characterizes the real employment opportunities. In order to identify the gender peculiarities of the changes in the regional employment structure, the authors suggested the methodology, based on the qualitative and quantitative approach to the assessment of the dynamics of the number of employed. The use of the index of dissimilarity allowed defining the share of employers of the same gender, which should have changed the sphere of activity provided that the employees of the other gender remain at their jobs, in order to achieve the equal distribution of men and women by economic activities. The obtained data confirm the necessity to implement the measures for the reduction of the gender segregation in the employment structure of the regional employment.

Keywords: gender employment structure by economic activities, gender segregation, index of dissimilarity, region, labour market

\section{Introduction}

One of the challenges of the modern labour market is gender segregation (or segregation on the basis of gender identity), which means a stable trend of employment of men and women within strictly defined economic activities, occupations and job positions (Baldwin et al, 2001).

Gender segregation has deep roots in the division of labour between the genders both in modern societies and societies of the past (Anker, 1998). It is manifested both within and between companies, spheres of employment and economic activities and represents a complex, multidimensional phenomenon. On the one hand, gender segregation is one of the results of modern society development, and on the other hand, it is the source of many problems of this society. Due to this fact, gender segregation draws close attention of scientists and politicians, who are trying to understand and analyze the complex causal relationships which form the basis of the emergence of segregation, as well as of its impact on the labour markets operation. The interest in this issue is connected with its central position in the maintenance and reproduction of gender inequality, which is observed in economic, social and political spheres, as well as with the consequences of segregation. High level of segregation is considered to be a significant factor of disproportions in the rates of remuneration for men and women, in career opportunities and, as a consequence, in the inequality of the opportunities of genders in the sphere of employment in general.

The labour market of any region is characterized by a certain level of gender segregation, and for objective assessment of this phenomenon it is necessary to have a clear understanding of how this level changes over the time, which processes at the labour market and in society facilitate the increase or decrease of gender asymmetry in the distribution of employees between economic activities and occupations and which economic consequences are caused 
by segregation. Thus, the analysis of the aspects of gender segregation is important in terms of both social justice and enhancement of the effectiveness of the use of labour resources (Sarycheva, 2011).

\section{Methods and Materials}

The highest level of gender segregation corresponds to the situation, when the activities are clearly divided into "male" and "female".

In order to identify the gender peculiarities of the changes in employment structure by economic activities, the number of employed was analyzed qualitatively and quantitatively.

The analysis of quantitative changes was carried out by classifying the economic activity according to the major trends of change in the number of employed men and women (Maltseva, Roshchin, 2006):

- 1 st group: activities, in which the number of men and women decreased;

- 2nd group: activities, in which the number of employed of both genders increased;

- 3rd group: activities, in which the number of employed men increased, and the number of employed women decreased;

- 4th group: activities, in which the number of employed men decreased, and the number of employed women increased.

To analyze the qualitative changes the economic activities were grouped in a different way; in particular, they were divided into three groups according to the employment by gender.

The economic activities, typical of the employees of different genders, were determined according to the methodology of Blau et al (Blau F.D., DeVaro J., 2006). Reference of the economic activity to a certain group is based on a comparison of the percent of women in the given sphere and in the total number of employed. An economic activity was considered as "predominantly female" if $p_{i t}>\left(P_{t}+10\right)$, and "predominantly male", if $p_{i t}<\left(P_{t}-10\right)$, where $p_{i t}$ - percent of women in the employed in the sphere $i$ in ${ }^{t}$ year, $P_{t}$ - percent of women in the total number of employed in economy. Other economic activities were regarded as "integrated" (Blau, Simpson, Anderson, 1998).

In order to measure the degree of gender segregation the index of dissimilarity, or the Duncan index $(I D)$, was used. This index shows the percentage of employees of the same gender, which would have had to change the scope of activities provided that the employees of other gender remain in their jobs, in order to achieve the equal distribution of men and women by economic activities. The index is calculated as follows (Sarycheva, 2011):

$$
I D=\frac{1}{2} \sum_{i=1}^{n}\left|\frac{W_{i}}{W}-\frac{M_{i}}{M}\right| \times 100 \%
$$

Where $i$ - the economic activity $i=\overline{1, n}$;

$W_{i}$ and ${ }^{M_{i}}$ - the numbers of women and men employed in economic activities respectively;

$W$ and $M$ - the total number of women and men employed in the economy.

The value of this index varies from 0 to $100 \%$, which reflects the absolutely segregated structure of employment.

\section{Results and Discussion}

Due to the economic reforms, connected with the transition from the planned to the market economy, the Mari El Republic along with the other Russian regions faced significant changes in all aspects of social life. Naturally, the labour sphere was involved in the current process. Women became more actively engaged in the labour activity, which is primarily evidenced by a significant increase in the share of women in the sphere of employment (Mari El, 2006, 2014) (Fig.1). 


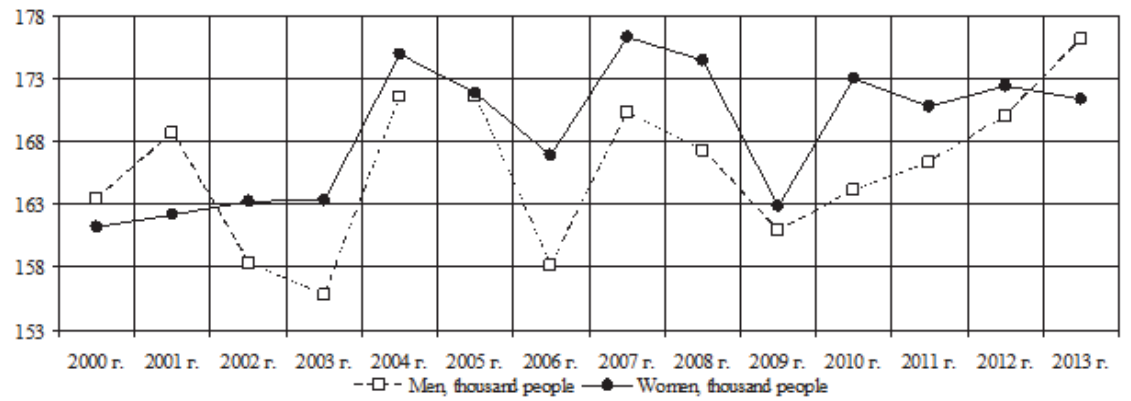

Figure 1 - The dynamics of the number of employed by genders

In 2013, in the region 171.3 thousand women were employed, which amounted of $49.3 \%$ of the total number of employed; in 2000, the value of this indicator was 162.2 thousand people. Position of women at the labour market is determined by the need for work, the demand of economy for the employees of this group, competitiveness and qualification of female employees, their ability to change job, profession, working conditions and the type of ownership as well as by the system of social protection in the sphere of labour.

The market reforms showed that socio-economic transformation had different impacts on the positions of men and women in society. The participation of male and female workforce in redistributive processes at the labour market was different not only in scale and directions of movement, but also in the results, which primarily influenced the gender relations in the sphere of labour and employment.

The first thing that came to attention when applying qualitative approach to the horizontal segregation analysis was the fact that, against the general tendency towards the increase in the number of employed, the gender processes in certain economic activities were heterogeneous (Table 1).

Table 1 - The dynamics of the number of employed by economic activities in terms of genders, 2013/2000 (thousand people)

\begin{tabular}{|l|c|c|c|c|c|c|}
\hline \multirow{2}{*}{ Economic activities } & \multicolumn{2}{|c|}{2000} & \multicolumn{2}{c|}{2013} & \multicolumn{2}{c|}{ Change } \\
\cline { 2 - 8 } & men & women & men & women & men & women \\
\hline Agriculture, hunting and forestry & $\mathbf{3 . 8}$ & 1.7 & $\mathbf{1 8 . 4}$ & 11.3 & $\mathbf{1 4 . 6}$ & $\mathbf{9 . 6}$ \\
\hline Mining operations & 0.3 & 0 & 1 & 0 & 0.7 & 0 \\
\hline Manufacturing & 30.1 & 29.7 & 39.1 & 30.2 & 9 & 0.5 \\
\hline Production and distribution of electricity, gas and water & 6.8 & 0.8 & 9.8 & 2.9 & 3 & 2.1 \\
\hline Construction & 25.2 & 7.1 & 32.3 & 4.8 & 7.1 & -2.3 \\
\hline Wholesale and retail trade & 14.4 & 21.4 & 18.7 & 31.5 & 4.3 & 10.1 \\
\hline Hotels and restaurants & 0.9 & 3.1 & 0.7 & 6.2 & -0.2 & 3.1 \\
\hline Transport and communication & 11.8 & 6.2 & 15.3 & 6.7 & 3.5 & 0.5 \\
\hline Financial activities & 1.1 & 4.3 & 1.2 & 3.4 & 0.1 & -0.9 \\
\hline Real estate transactions & $\mathbf{3 2 . 6}$ & $\mathbf{2 2 . 9}$ & 10 & $\mathbf{5 . 2}$ & $\mathbf{- 2 2 . 6}$ & $\mathbf{- 1 7 . 7}$ \\
\hline Public administration & 11.9 & 2.8 & 15.7 & 13 & 3.8 & 10.2 \\
\hline Education & 8 & 32 & 6.5 & 26.3 & -1.5 & -5.7 \\
\hline Healthcare & 1.8 & 15.3 & 3.7 & 20.1 & 1.9 & 4.8 \\
\hline Provision of other services & 14.7 & 13.9 & 3.7 & 9.7 & -11 & -4.2 \\
\hline
\end{tabular}

First of all, we should highlight two economic activities: real estate transactions and agriculture. These spheres were characterized by mass and diverse changes. Real estate transactions is the activity, in which employment reduced the most significantly (the numbers of women's and men's jobs decreased by 17.7 and 22.6 thousand people respectively). In agriculture, on the contrary, there was the largest increase in the number of employed women and men (9.6 and 14.6 thousand people respectively).

The classification of economic activities by the direction of dynamics in gender employment is presented in Table 2: 
Table 2 - The classification of economic activities by the direction of dynamics in gender employment

\begin{tabular}{|c|l|l|}
\hline Group No. & Trends in gender employment & Economic activities \\
\hline 1 & reduction in the number of employed of both genders & $\begin{array}{l}\text { Real estate transactions } \\
\text { Education } \\
\text { Provision of other services }\end{array}$ \\
\hline 2 & increase in the number of employed of both genders & $\begin{array}{l}\text { Agriculture } \\
\text { Manufacturing } \\
\text { Production and distribution of electricity, gas and water } \\
\text { Wholesale and retail trade } \\
\text { Transport and communication } \\
\text { Public administration } \\
\text { Healthcare }\end{array}$ \\
\hline 3 & $\begin{array}{l}\text { increase in the number of employed men, decrease in } \\
\text { the number of employed women }\end{array}$ & $\begin{array}{l}\text { Mining operations } \\
\text { Construction } \\
\text { Financial activities }\end{array}$ \\
\hline 4 & $\begin{array}{l}\text { decrease in the number of employed men, increase in } \\
\text { the number of employed women }\end{array}$ & \begin{tabular}{l} 
Hotels and restaurants \\
\hline
\end{tabular}
\end{tabular}

According to the analysis of gender trends in employment, the economic activities belonging to the group with the reduction of employed people refer to the sphere of services. These activities are real estate transactions, education and provision of other services. Such diversity shows that the crisis processes affected various spheres of the regional economy. The gender aspect of the changes in this group was primarily expressed in the fact that the number of employed men decreased more intensively than the number of employed women. The total number of the male jobs in the first group decreased by 63.5\%, and the number of employed women decreased by 40.1 thousand. In education, which is one of the most feminized activities, the number of employed men decreased by $18.8 \%$ which is largely due to the fact that military training, most teachers in which were men, was withdrawn from the school curricula. The number of female employees in the sphere of education decreased by $17.8 \%$. The number of employed in the sphere of provision of other utility, social and personal services reduced more than twice. The numbers of man and woman employees decreased by $75.5 \%$ and $31.9 \%$ respectively.

The second group with increasing employment included the following activities: agriculture; manufacturing; production and distribution of electricity, gas and water; wholesale and retail trade; transport and communication; public administration; healthcare. In the analyzed period, these activities faced a significant influx of female staff, which exceeded the growth rate of male employment in most economic activities of this group. However, we cannot consider that women "forced men out" of these activities. All male jobs were kept, but men evidently lost the competition for the newly created jobs. Therefore, we can make the following conclusion about the gender peculiarities of employment processes in the second group: in rapidly developing spheres of services the growth rates of the number of employed women were considerably higher, than the growth in the number of male staff (Sarycheva, Bakumenko, 2015). The emphasis is placed on agriculture, production and distribution of electricity, gas and water, which are the spheres, traditionally regarded as economic activities with predominantly male employment. In the analyzed period, in these spheres there was a tremendous influx of female staff, which significantly exceeded the growth rate of men employment (the growth by 1.4 and 2.5 times respectively). The analysis of the number of employed in public administration showed that the number of male working positions increased by 3.8 thousand, as for female working positions, their number increased by 11.2 thousand. In healthcare, the increase in the number of employed women exceeded the growth in the number of men, but the addition of 4.8 thousand people to 15.3 thousand women who had already worked in healthcare was not so significant, whereas the increase in the number of men from 1.8 to 3.7 thousand became a meaningful fact. It had an impact on the employment proportions in the industry by genders, since the share of women among the employed people decreased from $89.5 \%$ to $84.5 \%$.

The staffing processes in the third group of activities can be characterized as the increase in the number of employed men against the reduction in women's employment. At the same time, the influx of men was more significant than the "substitution" of the number of women, and as a result of these processes, the total number of employed in this group increased by 5.5 thousand people. In the context of the trend of outrunning decrease in the number of employed men, which is general for the economy of the Mari El Republic, the emergence of economic activities, in which there was a growth in a number of men against the decline in women's employment, is rather exciting and is certainly of great interest for the gender analysis of employment. Mining operations is the activity which involves the smallest number of 
people and the most masculinized structure of employment. In this sphere, there are practically no women working positions, but the growth in the number of employed men is very small. This is primarily due to the fact that this economic activity is not well-developed in the region. The most intensive "substitution" of female staff was observed in the sphere of construction. Men occupied almost $40 \%$ of working positions, which were previously held by women. Certainly, we cannot claim that in this sphere of activity women were dismissed, and men were employed at the positions of those women. This process was more complicated: women were dismissed from their jobs, and for men in most cases the jobs of some different kind were created. However, when applying the gender approach to the analysis, it is important to take into account the result of the dynamics of industrial employment disproportions by genders - the reduction of jobs for women and the men's jobs growth in the third group of economic activities.

The analysis of the number of employed in hotel and restaurant business, the only representative of the fourth group of activities, showed a decline in the number of men's jobs by 0.2 thousand and the increase in the number of women's jobs by 1.7 thousand. It should be pointed out that this sphere of activity is characterized by one of the lowest levels of average wages, which in the analyzed period had the tendency to further decrease in comparison to the general indicators of the Republic (wages are lower only in the sphere of provision of other services). Surely, it is the level of wages that can explain the outrunning growth in women's employment: men leave their jobs due to low wages, and women, having limited job opportunities, took the low-paid jobs at the enterprises of these spheres of activity (Sarycheva, Shvetsov, 2015).

Summing up the results of quantitative analysis of gender specifics of the horizontal changes in employment in the various spheres of economic activities in the Mari El Republic from 2000 to 2013, we can make the following conclusion: with an increase in the number of employed in several areas of economic activity, the increment rates of women's employment were outrunning.

The analysis of quantitative changes in the horizontal gender structure of employment showed that in 20005 of 14 economic activities of the region could be called "female": wholesale and retail trade $-59.8 \%$ of women working positions; hotels and restaurants - 77.5\%; financial activities - 79.6\%; education - 80.0\%, healthcare - 89,5\%. 7 activities could be regarded in 2000 as "male": agriculture; fishery and fish farming; mining operations; production and distribution of electricity, gas and water; construction; transport and communication; public administration, in which the shares of men among the employed people accounted for $69.1 \%, 100.0 \%, 100 \%, 78.0 \%, 65.6 \%$ and $81.0 \%$ respectively. In 2000, 3 activities were relatively balanced in terms of gender aspect of employment: manufacturing ( $49.7 \%$ of women in the number of employed); real estate operations, renting and provision of services (41.3\%); provision of other utility, social and personal services (48.6\%).

The qualitative shifts in the industrial structure in 2000-2013 resulted in the growth in the share of women in the total number of employed people in 7 activities. The trend of feminization in such "female" activity as wholesale and retail trade, when the share of women's working positions increased by $47.2 \%$ against quite low wages (for the particular region) can be assessed as a negative phenomenon of the concentration of women. The number of employed women also significantly increased in several "male" spheres of activity: in agriculture, where the ratio of employed men and women changed in favour of the latter by $7.1 \%$; in the companies of the sphere of production and distribution of electricity, gas and water, where the share of women increased by $12.8 \%$. The most significant increase in the number of employed women occurred in public administration, which was one of the four "male" activities as of 2000, and in the sphere of provision of other services, one of the "integrated" activities. In public administration the share of women increased by almost 5 times, and in provision of other services the increase of employed women was 23.8 percent. It should be noted that in healthcare, the most feminized economic activity, the share of men increased by 5 percent. At the same time in the most masculinized (as of 2013) activities, such as mining operation and construction, the share of employed women decreased by 6.1 and 9.0 percent respectively.

As a result of the interindustrial shifts in 2013, the number of "female" activities increased from 5 to 6 since "provision of other services" was added to these spheres. "Public administration" left the group of "male" activities, joined the activities, for which the number of employed men and women can now be considered as relatively equal (Wirth, 2001), and was replaced by "real estate transactions" (Table 3). 
Table 3 - The groups of economic activities in terms of gender employment

\begin{tabular}{|l|l|l|}
\hline Groups of activities & 2000 & 2013 \\
\hline \multirow{4}{*}{ "female" activities } & $\begin{array}{l}\text { Wholesale and retail trade } \\
\text { Hotels and restaurants } \\
\text { Financial activities } \\
\text { Education } \\
\text { Healthcare }\end{array}$ & $\begin{array}{l}\text { Wholesale and retail trade } \\
\text { Hotels and restaurants } \\
\text { Financial activities } \\
\text { Education } \\
\text { Healthcare } \\
\text { Provision of other services }\end{array}$ \\
\hline \multirow{3}{*}{ "male" activities } & $\begin{array}{l}\text { Agriculture } \\
\text { Mining operations } \\
\text { Production and distribution of electricity, gas and water } \\
\text { Construction } \\
\text { Transport and communication } \\
\text { Public administration }\end{array}$ & $\begin{array}{l}\text { Agriculture } \\
\text { Mining operations } \\
\text { Production and distribution of electricity, gas and water } \\
\text { Construction } \\
\text { Transport and communication } \\
\text { Real estate transactions }\end{array}$ \\
\hline "integrated" activities & $\begin{array}{l}\text { Manufacturing } \\
\text { Real estate transactions } \\
\text { Provision of other services }\end{array}$ & $\begin{array}{l}\text { Manufacturing } \\
\text { Public administration }\end{array}$ \\
\hline
\end{tabular}

Choice of occupation by men and women is connected with an individual assessment of the return of the job during the working life and first of all with the amount of wages. At the same time, according to traditions, it is suggested that the preferences of men in career choices are determined by the need to earn money in order to make provision for their families.

In general, the gender differences in wages are closely connected with the asymmetry of the gender structures of employment. The main negative consequence of the gender segregation is the inequality of the working results of men and women (Ogloblin, 1999). There is the following trend: the higher is the concentration of women in a certain economic activity, the lower is the ratio of the level of wages in this sphere to the average wages in the economy, which is illustrated by the data of Table 4. In this table the ratios of average wages to the shares of employed women are presented for the basic economic activities. Either women are concentrated in low-paid activities, or low wages are formed in areas, in which the concentration of female employment is higher (Ransom, Oaxaca, 2005).

Table 4 - The ratio of the degree of women concentration in the industries to the level of wages in the Mari El Republic, 2013

\begin{tabular}{|l|c|c|}
\hline Economic activities & $\begin{array}{c}\text { Share of women, employed in the } \\
\text { economic activity, } \%\end{array}$ & $\begin{array}{c}\text { The ratio of the average wages in the economic activity to the average } \\
\text { wages in the economy of the Mari El Republic, \% }\end{array}$ \\
\hline Mining operations & 0,0 & 86,7 \\
\hline Construction & 12,9 & 92,2 \\
\hline $\begin{array}{l}\text { Production and distribution of } \\
\text { electricity, gas and water }\end{array}$ & 22,8 & 114,1 \\
\hline Transport and communication & 30,5 & 114,4 \\
\hline Real estate transactions & 34,2 & 82,1 \\
\hline Agriculture, hunting and forestry & 38,0 & 79,4 \\
\hline Manufacturing & 43,6 & 106,1 \\
\hline Public administration & 45,3 & 163,8 \\
\hline Wholesale and retail trade & 62,7 & 76,8 \\
\hline Provision of other services & 72,4 & 66,5 \\
\hline Financial activities & 73,9 & 171,1 \\
\hline Education & 80,2 & 81,8 \\
\hline Healthcare & 84,5 & 76,9 \\
\hline Hotels and restaurants & 89,9 & 65,4 \\
\hline
\end{tabular}

Only three spheres of activities: mining operations, construction and financial activities stand out against the stable dependence between the share of women, employed in a particular activity, and the relative amount of average wages in this activity in the Mari El Republic as oa 2013.

Men dominate in the first two areas, and low wages are explained by the high share of private enterprises, which provide jobs in the given activities. Financial sphere is characterized by the opposite situation. In spite of the overbalance of female employees, the average wages outstrip the indicators of all other activities. However, it is easy to notice that in 
the first case the share of women in the industry does not increase, while in financial sphere the concentration of men increases over time. This fact illustrates the mechanism of formation of the gender segregation at the labour market and its influence at the gender gap in wages: as soon as an economic activity becomes highly profitable due to the reasons related to favourable economic situation, the share of men, employed in this activity, begins to grow.

It should be noted that the level of wages, as well as the degree of concentration of women in an economic activity, are too aggregated indicators to reflect the size of gain or loss of each gender group from the employment in the given sphere. The main determinants of the size of earnings of an employer are the parameters of their human capital: education and working experience. Currently, in terms of formal education we can talk of gender equality. At the same time, in terms of the duration of employment and hence the level of accumulated professional experience, women on average give way to men. It is explained by the fact that the women's responsibility to care for children makes them interrupt their employment for a while. Besides, the implementation of «dual function» by the employed women implies that they should spend less time on work for wages than men. As a consequence, women choose such activities, which allow more flexible working hours and provide either reduced working days or alternation of full working days with off days.

The analysis of the dynamics of the index of dissimilarity from 2000 to 2013 showed that during the whole period under consideration the distribution of men and women by economic activities was nonuniform (Fig. 2).

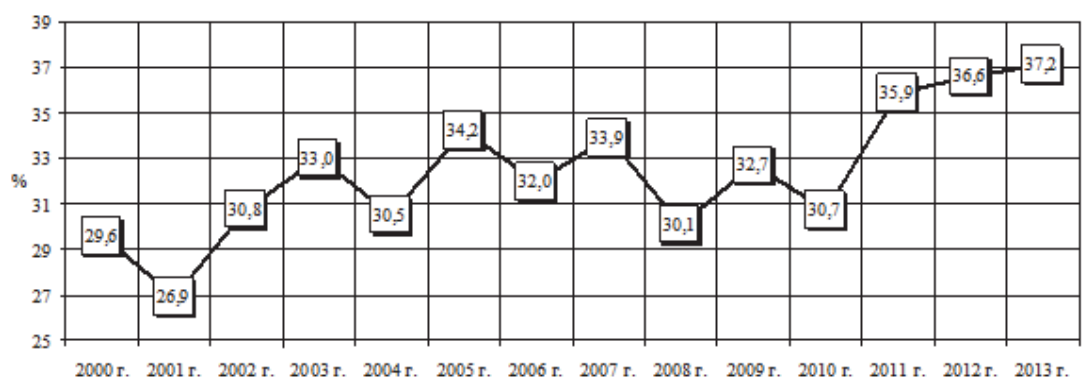

Figure 2 - The dynamics of the index of dissimilarity, \%, 2000-2013

In 2001 the index of horizontal segregation was minimal and amounted to only 26.9. In 2013, the index of dissimilarity by the economic activities was $37.2 \%$. We can confidently note that in the Mari El Republic there is a division of activities into "male" and "female", and year by year this separation increases. In order to balance the group composition by gender, almost $38 \%$ of men or women would have had to change the sphere of activity. High level of the gender segregation is not the specific feature of the Mari El Republic since the same phenomenon is also observed in Russia as a whole.

\section{Conclusion}

The results of the conducted analysis show that the gender segregation has increased for the period of social transformation: both men and women became even more focused on "their" sectors of economy. The main trend in segregation is deepening. Thus, it was proved that the regional labour market faces both discrimination and a mechanism of women' self-selection, which do not allow them to occupy the same positions as men. Active involvement of women in the labour activity has not led in the elimination of differences between men and women in the sphere of employment. In spite of the similar levels of economic activity and kinds of labour activities of men and women during the lifecycle, women continue to work in the conditions of horizontal and vertical segregation at the labour market, and earn on the average lower wages. Thus, in order to eliminate the economic foundations of the gender inequality, it is not sufficient to ensure equal involvement of men and women in the labour activity. For this purpose, it is essential to change the structure of demand at the market, the procedures for hiring and promoting staff and to enhance the significance and prestige of the positions, occupied by women.

\section{Acknowledgment}

The study was carried out with financial support from the Russian Foundation for Humanities within the project for conducting research "Demographic and economic potential of the region: the macrosystem approach", the project No. 1502-00567. 


\section{References}

Anker, R. (1998) Gender and Jobs: Sex Segregation of Occupations in the World. Geneva: International Labour Office.

Baldwin, et al. (2001) A Hierarchical Theory of Occupational Segregation and Wage Discrimination. Economic Inquiry. No. 39 (1); 2001, 94-110

Blau, F.D., DeVaro J. (2006). New Evidence on Gender Difference in Promotion Rates: An Empirical Analysis of a Sample of New Hires. NBER WP\#12321, 2006.

Blau, F.D., Simpson P., Anderson D. (1998). Continuing Progress? Trends in Occupational Segregation in the United States over the 1970's and 1980's. NBER Working Paper No. 6716,1998.

Maltseva, I.O., Roshchin, S.U. (2006). Gender segregation and mobility in the Russian labor market. Moscow: SU-HSE Publishing House.

Mari El. (2006). Stat. coll. Territorial authority of Federal State Statistics Service in the Republic of Mari El. $419 \mathrm{p}$.

Mari El. (2014). Stat. coll. Territorial authority of Federal State Statistics Service in the Republic of Mari El. $419 \mathrm{p}$.

Ogloblin, C.G. (1999) The Gender Earnings Differential in the Russian Transition Economy. Industrial and Labor Relations Review. No. 52(4). 1999, 602-627.

Ransom, M., Oaxaca R.L. (2005) Intrafirm Mobility and Sex Differences in Pay. Industrial and Labor Relations Review. No. 58(2). 2005, 219-237.

Sarycheva, T.V. (2011). The Analysis of The Gender Segregation and Mobility in Regional Labour Market. Economy, Statistics And Informatics. Umo Bulletin No. 6 (1); 2011, 169-174

Sarycheva, T.V., Bakumenko, L.P. (2015). The Conceptual Approaches to the Analysis of the Labour Market and Employment. Review of European Studies; Vol. 7, No. 8; 2015, 343-355. DOI: 10.5539/res.v7n8p343

Sarycheva, T.V., Shvetsov, M.N. (2015). Statistical Approaches to the Evaluation of the Demand and Supply at the Labour Market Based on Panel Data. Review of European Studies; Vol. 7, No. 8; 2015, 356-367. DOI:10.5539/res.v7n8p356

Wirth, L. (2001). Breaking through the Glass Ceiling: Women in Management. Geneva: ILO. 